\title{
Comparative proteomic analysis of different developmental stages of the edible mushroom Termitomyces heimii
}

Norasfaliza Rahmad, Jameel R Al-Obaidi, Noraswati Mohd Nor Rashid, Ng Boon Zean, Mohd Hafis Yuswan Mohd Yusoff, Nur Syahidah Shaharuddin, Nor Azreen Mohd Jamil and Norihan Mohd Saleh

\begin{abstract}
Background: Termitomyces heimii is a basidiomycete fungus that has a symbiotic relationship with termites, and it is an edible mushroom with a unique flavour and texture. T. heimii is also one of the most difficult mushrooms to cultivate throughout the world. Little is known about the growth and development of these mushrooms, and the available information is insufficient or poor. The purpose of this study was to provide a base of knowledge regarding the biological processes involved in the development of T. heimii. The proteomic method of 2 dimensional difference gel electrophoresis 2D-DIGE was used to determine and examine the protein profiles of each developmental stage (mycelium, primordium and fruiting body). Total proteins were extracted by TCA-acetone precipitation.
\end{abstract}

Results: A total of 271 protein spots were detected by electrophoresis covering pH 3-10 and 10-250 kDa. Selected protein spots were subjected to mass spectrometric analyses with matrix-assisted laser desorption/ionisation (MALDI TOF/TOF). Nineteen protein spots were identified based on peptide mass fingerprinting by matching peptide fragments to the NCBI non-redundant database using MASCOT software. The 19 protein spots were categorised into four major groups through KEGG pathway analysis, as follows: carbohydrate metabolism, energy metabolism, amino acid metabolism and response to environmental stress.

Conclusions: The results from our study show that there is a clear correlation between the changes in protein expression that occur during different developmental stages. Enzymes related to cell wall synthesis were most highly expressed during fruiting body formation compared to the mycelium and primordial stages. Moreover, enzymes involved in cell wall component degradation were up-regulated in the earlier stages of mushroom development.

\section{Background}

The edible mushroom Termitomyces heimii is an agaric-type fungus in the family Lyophyllaceae. It was first discovered in India during the late 1970s [1]. The fungus is also known as "termite mushroom" due to its symbiotic relationship with termites, insects belonging to the subfamily Macrotermitinae. These basidiomycete mushrooms are distributed throughout tropical and subtropical areas of Africa and Asia. Termitomyces fungi are cultivated on a special substrate in the termite nest called the fungus comb [2]. In most Macrotermes termites, the fungus comb is composed of their primary faeces, which is mostly undigested dead plant matter

\footnotetext{
*Correspondence: jr_alobaidi@yahoo.com

Agro-biotechnology Institute Malaysia (ABI), c/o MARDI Headquarters, Serdang, Selangor 43400, Malaysia
}

(c) 2014 Rahmad et al.; licensee BioMed Central Ltd. This is an Open Access article distributed under the terms of the Creative Commons Attribution License (http://creativecommons.org/licenses/by/4.0), which permits unrestricted use, distribution, and reproduction in any medium, provided the original work is properly credited. The Creative Commons Public Domain Dedication waiver (http://creativecommons.org/publicdomain/zero/1.0/) applies to the data made available in this article unless otherwise stated.
[3]. After the termites grow, they feed on the mature parts of the fungus comb and aggregated asexual spores, called fungal nodules. Dead plant materials are thought to be efficiently and strongly degraded in the symbiotic system because fungus-growing termites, unlike many other termites, do not produce faeces rich in organic matter [4]. Thus, the symbiotic fungi are responsible for the efficient decomposition of plant materials by fungusgrowing termites. Termitomyces heimii is valuable because it has a delicious taste. In addition, the fungus has potential therapeutic uses in blood pressure and blood lipid regulation, the immune response, apoptosis and infection [5]. Its cultivation remains challenging, and numerous worldwide attempts have been made with varying degrees of success. However, all attempts have fallen short as economical cultivation methods [6]. There are limited reports 
on the biochemical composition of the fungus. This may be due to the difficulty in obtaining wild fruit bodies, as these are seasonal mushrooms. Studies to determine the mechanisms involved in the mushroom's development are necessary to provide insight into potential fungus cultivation processes. Proteomic approaches, such as two-dimensional difference gel electrophoresis (2D-DIGE) in combination with mass spectrometry (MS), have been widely applied to identify and profile proteins expressed in pathogenic [7,8] and edible basidiomycetes [9]. A number of studies have convincingly demonstrated that DIGE and MS are complementary proteomics approaches, and the use of both approaches in combination provides deeper insight into the proteome. To better understand the mushroom's systematic response to environmental stress and protein-protein interactions during different developmental stages, we employed proteomic approaches in this study.

\section{Results}

\section{D-DIGE PAGE at different stages of development}

To compare the termite mushroom proteome at each of its three developmental stages, total proteins were extracted from the mycelia, primordia and fruiting bodies. For 2D-DIGE, protein extracts were labelled with fluorochromes and mixed prior to separation via 2D electrophoresis. Figures (1A) and (1B) show representative images of the gels from experiments 1 and 2, respectively, in which the separated proteomes can be observed. We normalised and detected the protein spots
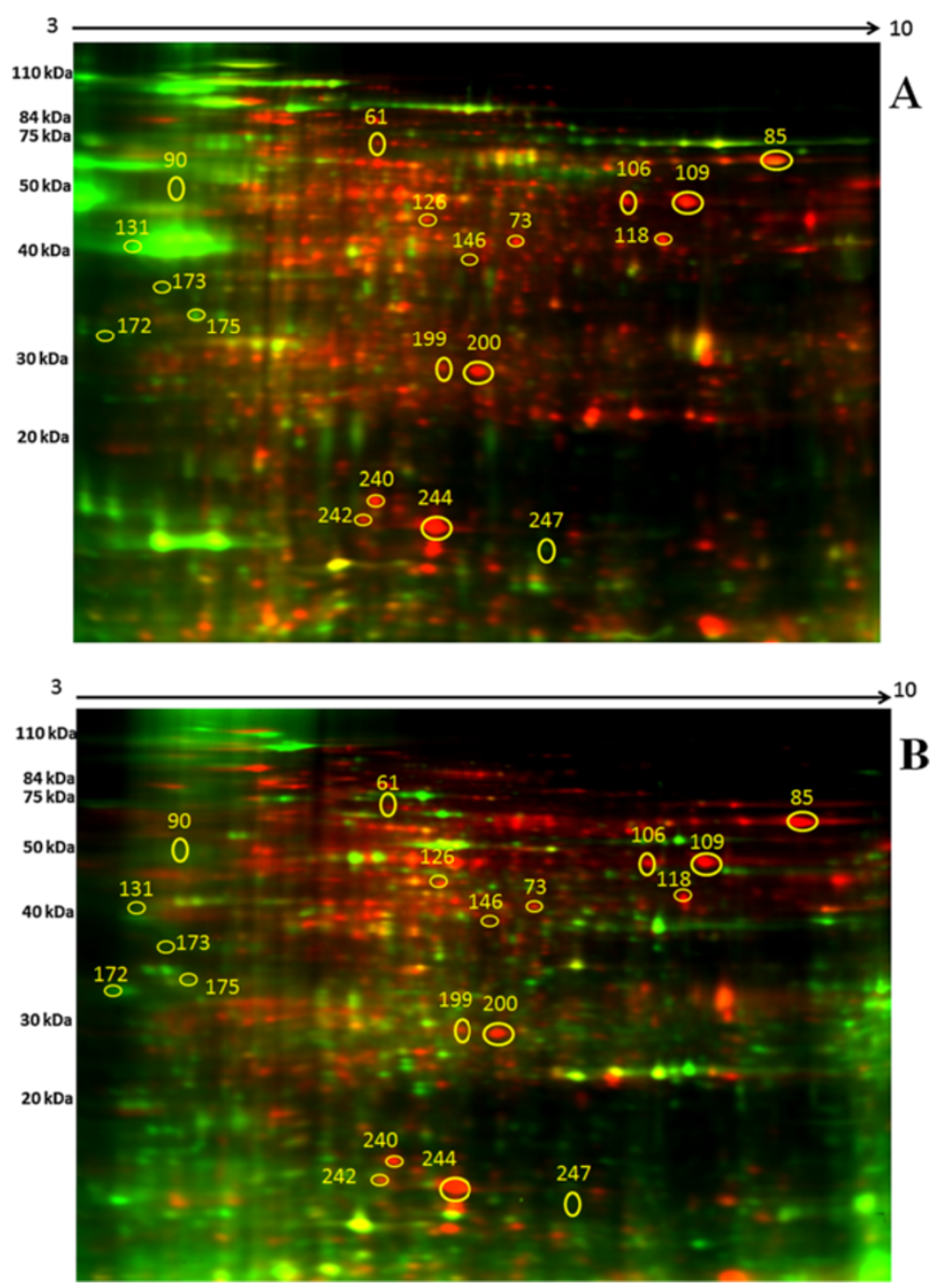

Figure 1 Representative 2D-DIGE expression maps of the termite mushroom (Termitomyces heimii) labelled with fluorescent dyes (Cy2, Cy3, and Cy5). The 2D-DIGE image of protein spots compares (A) the mycelial proteins labelled with Cy3, the primordial proteins labelled with Cy5, and the internal standard labelled with Cy2. (B) The mycelial protein was labelled with Cy3, fruiting body protein was labelled with Cy5, and the internal standard was labelled with Cyz. 
with Advanced PDQuest 2-D analysis software (Bio-Rad, Hercules, CA, USA). The optical density of each protein spot was evaluated using Student's t-test. The results from the two experiments reveal approximately 271 protein spots with molecular masses ranging from $10 \mathrm{kDa}$ to 250 $\mathrm{kDa}$ and pIs ranging from 3-10. Each stage has a different and unique proteome map (data not shown). For this preliminary study, and to avoid generating a massive amount of data, we selected 19 protein spots with an average ratio value $>1$ and $p$ value $<0.01$ that were present in both experiments for identification with MALDI-TOF.

The 19 proteins were subjected to MS and subsequent database searches; of these, 12 proteins (represented by 14 spots) had a known function, while five proteins had unknown functions (Table 1). Using functional information from the KEGG and Swiss-Prot pathway databases, we assigned biological functions to the identified proteins (Figure 2).

\section{Discussion}

During the development of all basidiomycete fungi, the vegetative mycelium stage transforms into a fruiting body via an intermediate primordium stage, which is a complicated and critical process [10]. Understanding the molecular mechanisms underlying this process has long been a goal in basidiomycete research. By defining the proteome at each developmental stage, we can obtain a broader understanding of the mushroom fruiting process [11].

This study is one of the first reports of the termite mushroom proteome. Unlike classical proteomic studies that produce large quantities of information, we screened different developmental stages of the termite mushroom for proteins with significantly but consistently altered expression levels during development. Therefore, we focused on 19 spots that passed our screening criteria. NADP-dependent glutamate dehydrogenase (NADPGDH) is an intermediate enzyme in fungal ammonium absorption and converts 2-oxoglutarate to glutamate [12]. NADP-GDH is positioned at the border of carbon and nitrogen metabolism and is potentially involved in the regulation of these processes [13]. Although the cofactor enzyme NADH dehydrogenase (spot \#173) was down-regulated during fruiting body development, we found that NADP-GDH (spot \#109 and 106) was slightly up-regulated in the primordia stage compared to the mycelium. However, when we compared its expression between fruiting bodies and primordia, it was similarly, but not significantly, up-regulated. Metallophosphoesterase (spot \#242) had a similar expression profile. It was not significantly down-regulated during the primordial stage; however, it was highly up-regulated in fruiting bodies. This was expected, as the levels of cell wall enzymes likely increase after fruiting bodies are harvested in basidiomycetes [14]. Carbohydrate esterase
4 (Spot \#175) hydrolyses proteins, especially pectins. We found that it was significantly up-regulated during primordial formation, but its expression significantly decreased during fruiting body formation. It was previously reported that carbohydrate esterase 4 was upregulated in fungal cells during their interactions with their host cells $[15,16]$. In addition, Yang et al. [17] found that carbohydrate esterase was expressed during fruiting body formation of the closely related edible mushroom Termitomyces albuminosus, which suggests that termite mushrooms can degrade lignin. The mushroom cooperates with the enzymes produced by the fungus-growing termite to degrade the cellulose and hemicellulose of plant cells, which supports the wellcoordinated cooperation hypothesis and potentially explains the symbiotic relationship between the termite and the fungus [18].

We found that translation elongation factor 1-alpha (TEF $\alpha 1$ ) was up-regulated in the primordial stage compared to the mycelium. While the expression of the protein in the fruiting stage was not significantly down-regulated compared to its expression in the mycelium stage, additional translation factors are likely involved. TEF $\alpha 1$ is thought to play an important and major role in the regulation of cell wall morphogenesis [19]. Similarly, TEF $\alpha 1$ was up-regulated in the basidiomycete Pleurotus tuberregium during the transition from mycelium to primordium [20].

Two spots (\#199 and \#200) represented cysteine peroxiredoxin. Peroxiredoxins are a class of fungal antioxidants that reduce hydroperoxides to alcohols [21]. We found that the protein was highly expressed in the primordia and was significantly higher in fruiting bodies compared to the mycelium. Cysteine peroxiredoxin usually localises to the cytosol and mitochondria. In eukaryotic cells, cysteine peroxiredoxin is highly expressed in various isoforms and, despite being less efficient than catalase, cysteine peroxiredoxin likely contributes to the protection of the plasma membrane against lipid peroxide oxidation [22]. This may be why cysteine peroxiredoxin levels increase during fungal development. Two different proteins involved in the glycolytic pathway, phosphoglucomutase (spot \#61) and fructose 1,6 bisphosphate aldolase (spot \#146), did not significantly change during the primordia stage; however, both proteins were significantly up-regulated during fruiting body formation. Insignificant changes in the levels of proteins related to the glycolytic pathway may lead to changes in glycolysis, gluconeogenesis, and mitochondrial function, which may be beneficial for nascent fungal cells adapting to an anaerobic environment [23]. Increased levels of these proteins may be necessary for the development of the rigid cell wall during fruiting body formation [24]. Sulphite reductase (spot \#126) is another enzyme 
Table 1 Proteins identified from the differential 2D-DIGE analysis obtained from 3 different developmental stages (mycelium, primordium and fruiting bodies) of the edible mushroom Termitomyces heimii

\begin{tabular}{|c|c|c|c|c|c|c|c|c|c|c|c|c|c|}
\hline \multirow[t]{2}{*}{ Spot no } & \multirow[t]{2}{*}{ Protein name } & \multirow[t]{2}{*}{ Accession no. } & \multirow[t]{2}{*}{${ }^{\mathrm{a}}$ Protein MW } & \multirow[t]{2}{*}{ Protein $\mathrm{pl}$} & \multirow{2}{*}{$\begin{array}{l}\text { Peptide } \\
\text { count }\end{array}$} & \multirow{2}{*}{$\begin{array}{l}\text { Protein } \\
\text { score }\end{array}$} & \multirow{2}{*}{$\begin{array}{l}\text { Protein } \\
\text { score C.I\% }\end{array}$} & \multirow[t]{2}{*}{ Total ion } & \multirow{2}{*}{$\begin{array}{l}\text { Total ion } \\
\text { score C.I\% }\end{array}$} & \multicolumn{4}{|c|}{ Average ratio value } \\
\hline & & & & & & & & & & ${ }^{\mathrm{b}} \mathrm{P} / \mathrm{M}$ & $p$ value & ${ }^{\mathrm{C}} \mathrm{F} / \mathrm{M}$ & $p$ value \\
\hline 172 & Predicted protein [Laccaria bicolor S238N-H82] & gi|170097613 & 73,362 & 5.2 & 8 & 459 & 100 & 437 & 100 & -1.4 & 0.14 & -7.4 & 0.00057 \\
\hline 109 & NADP-glutamate dehydrogenase [Laccaria bicolor] & gi|1 101027 & 48,444 & 6 & 8 & 348 & 100 & 317 & 100 & 5.9 & 0.026 & 42.0 & 0.00042 \\
\hline 106 & NADP-glutamate dehydrogenase [Laccaria bicolor] & gi|1 101027 & 48,444 & 6 & 9 & 342 & 100 & 303 & 100 & 1.2 & 0.58 & 16.9 & 0.0021 \\
\hline 247 & $\begin{array}{l}\text { Translation elongation factor 1-alpha [Uromyces } \\
\text { polygoni-avicularis] }\end{array}$ & gi|197726092 & 17,846 & 8.6 & 5 & 215 & 100 & 184 & 100 & 5.8 & 0.0014 & -1.7 & 0.069 \\
\hline 199 & Cysteine peroxiredoxin [Laccaria bicolor S238N-H82] & gi|170090830 & 25,089 & 5.8 & 5 & 165 & 100 & 95 & 100 & 1.7 & 0.12 & 8.2 & 4.50E-06 \\
\hline 175 & $\begin{array}{l}\text { Carbohydrate esterase family } 4 \text { protein } \\
\text { [Laccaria bicolor S238N-H82] }\end{array}$ & gi|170093812 & 27,286 & 6.2 & 3 & 159 & 100 & 149 & 100 & 10.9 & 0.00094 & 3.3 & 0.0099 \\
\hline 200 & Cysteine peroxiredoxin [Laccaria bicolor S238N-H82] & gi|170090830 & 25,089 & 5.8 & 5 & 145 & 100 & 104 & 100 & 1.8 & 0.076 & 33.6 & $1.20 \mathrm{E}-06$ \\
\hline 61 & Phosphoglucomutase [Micromonaspusilla CCMP1545] & gi|303273426 & 64,752 & 5 & 6 & 126 & 100 & 114 & 100 & -1.2 & 0.76 & 4.1 & 0.0093 \\
\hline 146 & $\begin{array}{l}\text { Fructose 1,6-bisphosphate aldolase [Laccaria bicolor } \\
\text { S238N-H82] }\end{array}$ & gi|170106499 & 38,916 & 5.5 & 7 & 126 & 100 & 98 & 100 & 1.6 & 0.027 & 12.0 & $9.70 \mathrm{E}-06$ \\
\hline 118 & Predicted protein [Laccaria bicolor S238N-H82] & gi|170100663 & 51,868 & 6.6 & 5 & 115 & 100 & 103 & 100 & 17.7 & 0.003 & 16.6 & 0.0016 \\
\hline 126 & Putative sulfite reductase [Janibacter sp. HTCC2649] & gi|84497034 & 11,622 & 6.3 & 3 & 97 & 100 & 80 & 100 & 1.2 & 0.31 & 5.4 & 0.00019 \\
\hline 131 & Aspartic peptidase A1 [Laccaria bicolor S238N-H82] & gi|170091822 & 44,125 & 5 & 6 & 86 & 98 & 66 & 99 & 9.2 & 0.00012 & 1.1 & 0.58 \\
\hline 90 & $\begin{array}{l}\text { Hypothetical protein MPER_03344 } \\
\text { [Moniliophthoraperniciosa FA553] }\end{array}$ & gi|238605335 & 18,291 & 8 & 1 & 85 & 97 & 80 & 100 & 19.1 & 0.00056 & 1.2 & 0.59 \\
\hline 240 & DNA primase [Oceanicolagranulosus HTCC2516] & gi|89070862 & 69,526 & 6.8 & 13 & 83 & 96 & 37 & 0 & 47.4 & 7.00E-07 & 12.6 & $2.90 \mathrm{E}-06$ \\
\hline 244 & $\begin{array}{l}\text { (p)ppGppsynthetase I SpoT/RelA } \\
\text { [Actinobacillussuccinogenes 130Z] }\end{array}$ & gi|152978696 & 70,073 & 8 & 7 & 71 & 33 & 55 & 91 & 1.2 & 0.08 & 47.7 & 7.20E-07 \\
\hline 73 & $\begin{array}{l}\text { Hypothetical protein MPER_10776 } \\
\text { [Moniliophthoraperniciosa FA553] }\end{array}$ & gi|238582725 & 28,866 & 7.2 & 1 & 66 & 0 & 66 & 99 & 65.7 & 0.00014 & 37.3 & 0.00012 \\
\hline 242 & Metallophosphoesterase [Spirosomalinguale DSM 74] & gi|284036135 & 26,893 & 5.8 & 1 & 64 & - & 64 & 99 & -2.4 & 0.013 & 5.3 & 0.0011 \\
\hline 85 & $\begin{array}{l}\text { Hypothetical protein Phum_PHUM233470 } \\
\text { [Pediculushumanuscorporis] }\end{array}$ & gi|242010560 & 222,895 & 9.2 & 14 & 63 & - & 63 & 99 & 19.9 & 2.80E-06 & 99.3 & $1.60 \mathrm{E}-06$ \\
\hline 173 & $\begin{array}{l}\text { NADH dehydrogenase (quinone) [Opitutus } \\
\text { terrae PB90-1] }\end{array}$ & gi|182412569 & 45,006 & 6.8 & 1 & 61 & - & 61 & 98 & 12.5 & $5.80 \mathrm{E}-05$ & 2.0 & $3.10 \mathrm{E}-03$ \\
\hline
\end{tabular}

aProtein Molecular Weight; ${ }^{\mathrm{b} P r i m o r d i u m} /$ Mycelium; ${ }^{\mathrm{C}}$ Fruiting bodies/Mycelium; +/-up-regulation/down-regulation. 


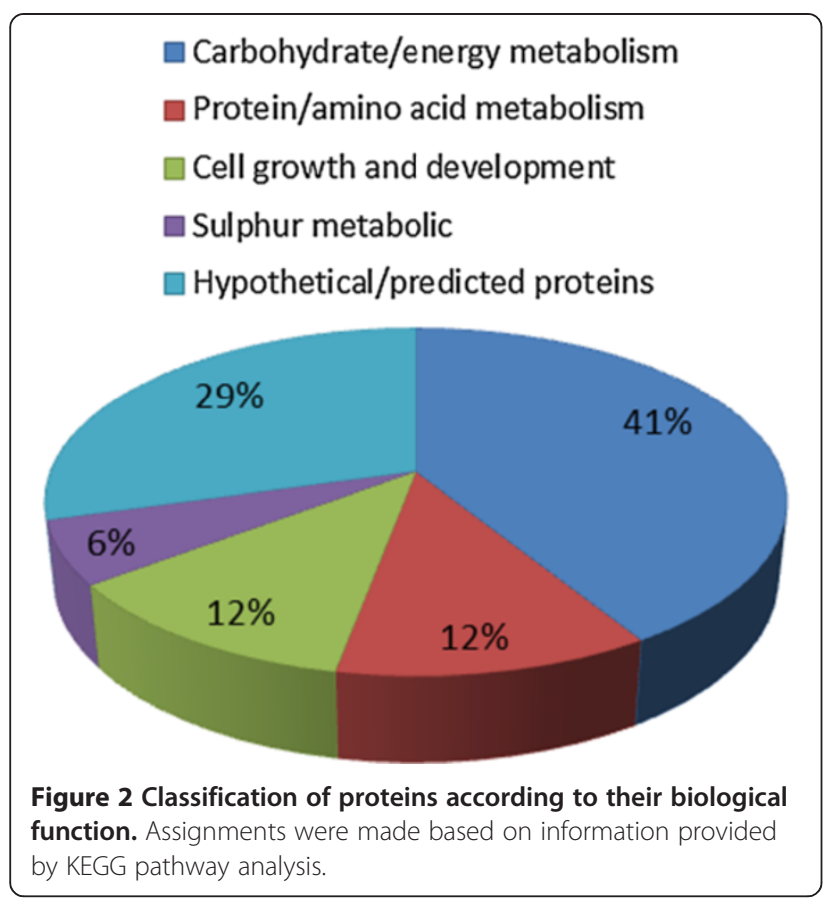

we detected that slightly changes during primordia formation and significantly changes during fruiting body formation. Although studies have been performed on bacterial cells, there is little information available on the functional role of sulphite reductase in mushroom development, except that it plays a role in sulphur assimilation in yeast during fermentation [25].

Aspartic peptidase A1 belongs to the protease family. We found that it was highly expressed during primordial development (spot \#131), but its expression dramatically decreased during fruiting body formation. The enzyme was previously isolated from the basidiomycete fungus Piptoporus soloniensis [26], but it did not have a clear role in mushroom development. It is possible that aspartic peptidase A1 is down-regulated because the termite mushroom is a non-pathogenic fungus. The same expression pattern was observed for DNA primase (spot \#240), although it was highly expressed after the mycelium stage, which may be due to the decrease in meiosis of fruiting body cells after a high level of meiosis during the primordial stage [27]. ppGpp guanosine pentaphosphate (spot \#244) was also highly expressed during fruiting body development. The enzyme is an alarmone, which is involved in the stringent bacterial response [28], resulting in the inhibition of RNA synthesis when there is a shortage of amino acids. To the best of our knowledge, this is the first report describing the up-regulation of ppGpp guanosine pentaphosphate in basidiomycetes. To further understand the proteinprotein interactions that occur during mushroom development, we created a protein network (Figure 3) using the STRING protein interaction database (http:// string-db.org/) using the identified proteins with known functions as input with a medium level of confidence [29]. The two proteins involved in the glycolytic pathway, phosphoglucomutase and fructose 1,6-bisphosphate aldolase, had the highest number of interactions ( 7 and 6 , respectively). The interaction network revealed the importance of these two proteins in glycolytic regulation, as these two proteins were connected to other enzymes involved in the pathway, such as glucose-6-phosphate isomerase and triose phosphate isomerase. The proteins with the highest number of connections were those that were up-regulated during fruiting body formation. The expression of these proteins may be necessary to develop the rigid cell wall and rapid cell expansion that are characteristic of fruiting body formation [24]. Cysteine peroxiredoxin was highly expressed during fruiting body formation, and we identified a single connection to triose phosphate isomerase. Triose phosphate isomerase is related to the glycolytic pathway, and this interaction may explain the role of cysteine peroxiredoxin in plasma membrane integrity. Together with cell wall formation, the interaction between triose phosphate isomerase and cysteine peroxiredoxin may be necessary for fruiting body formation [14,24].

\section{Conclusion}

The identification of proteins with potential roles in $T$. heimii mushroom development could provide useful information regarding fruiting body formation, which is possibly one of the most important developmental events in the life cycle of this mushroom, as it allows the formation of propagative structures. While altered protein expression may be physiologically relevant to the fungus and can facilitate changes in metabolism via different pathways, it may also be directly involved in the fruiting body development of $T$. heimii, a rare, highly desirable, edible seasonal fungus. We are currently working to obtain more information on the proteome of each developmental stage of the fungus by utilising various proteomic tools, such as liquid chromatography-based separation and label-free quantitative proteomics. These tools can be used to ultimately improve the cultivation methods of $T$. heimii.

\section{Methods \\ Samples}

Termitomyces heimii were collected during the rainy and wet season at Semenyih $\left(2.9500^{\circ} \mathrm{N}, 101.8500^{\circ} \mathrm{E}\right)$, Selangor, Malaysia. Mycelia of T. heimii were cultured on modified Hagem Modess (HM) media and incubated for 3 weeks (Figure 4). Samples at different stages of development (mycelia, primordia and fruiting bodies) were immediately frozen by submerging the samples in liquid nitrogen. The samples were then stored at $-80^{\circ} \mathrm{C}$ for further use. 


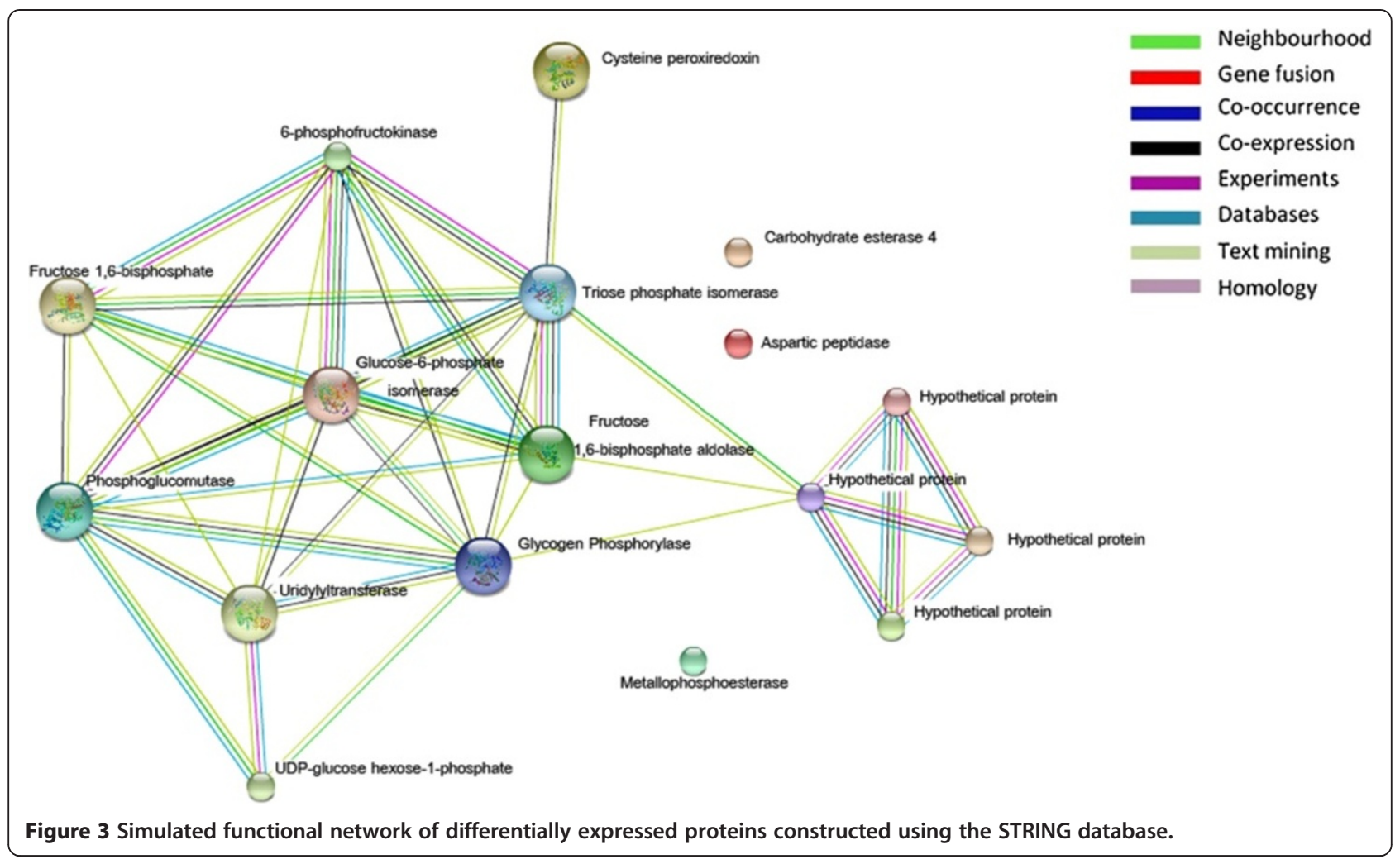

\section{Protein extraction}

Separate samples were ground using a mortar and pestle in liquid nitrogen. Protein extraction was carried out using TCA acetone precipitation [30]. Pellets were resuspended in lysis buffer containing $30 \mathrm{mM}$ Tris- $\mathrm{HCl}$, $\mathrm{pH}$ 8.8, $7 \mathrm{M}$ urea, $2 \mathrm{M}$ thiourea and 4\% CHAPS. Protein quantitation was conducted with a Bradford kit (BioRad, USA) with bovine serum albumin as a standard.

\section{D-DIGE}

\section{CyDye labelling}

Two experiments with 3 biological replicates each were performed. Each proteome was labelled with an appropriate fluorochrome (Cy2 for the internal standard, $\mathrm{Cy} 3$ for the mycelial protein and $\mathrm{Cy} 5$ for the primordial protein). In the second experiment, the proteins were labelled similarly to those in the 1st experiment, except that Cy5 was used to label the fruiting body protein as shown in Figure 1B. For each sample, $30 \mu \mathrm{g}$ protein was mixed with $1.0 \mu \mathrm{l}$ diluted CyDye, and kept in the dark on ice for $30 \mathrm{~min}$. Samples from each pair were labelled with $\mathrm{Cy} 3$ and $\mathrm{Cy} 5$, respectively, and an internal standard with Cy2 was run on each gel. The labelling reaction was terminated by adding $1.0 \mu 10 \mathrm{mM}$ lysine to each sample and incubating in the dark on ice for an additional $15 \mathrm{~min}$. The labelled samples were then mixed together. The $2 \times 2$-D sample buffer ( $8 \mathrm{M}$ urea,
4\% CHAPS, $20 \mathrm{mg} / \mathrm{ml} \mathrm{DTT,} \%$ pharmalytes and a trace amount of bromophenol blue), $100 \mu$ l destreak solution and rehydration buffer (7 M urea, $2 \mathrm{M}$ thiourea, $4 \%$ CHAPS, $20 \mathrm{mg} / \mathrm{ml}$ DTT, $1 \%$ pharmalytes and a trace amount of bromophenol blue) were added to the labelling mixture to bring the total volume to $250 \mu \mathrm{l}$. The solution was mixed well and spun down before loading the labelled samples into a strip holder.

\section{IEF and SDS-PAGE}

The isoelectric focusing step (IEF) was carried out on a PROTEAN $^{\circ} 112^{\text {ru }}$ IEF cell (BioRad) by applying the samples to $13 \mathrm{~cm}$ Immobiline ${ }^{\text {tm }}$ DryStrip gels (IPG), with a linear $\mathrm{pH}$ range of 3-10 (GE Healthcare). Rehydration was performed at $250 \mathrm{~V}$ for 2 hours in the linear mode followed by $250 \mathrm{~V}$ constant for 2 hours, $250-5000 \mathrm{~V}$ for 4 hours in the linear mode and $5000 \mathrm{~V}$ constant for a total of 8 hours and $35 \mathrm{kvh}$. Upon completion of IEF, the IPG strips were incubated in freshly made equilibration buffer-1 (50 mM Tris- $\mathrm{HCl}, \mathrm{pH}$ 8.8, $6 \mathrm{M}$ urea, 30\% glycerol, 2\% SDS, a trace amount of bromophenol blue and $10 \mathrm{mg} / \mathrm{ml}$ DTT) for 15 minutes with gentle shaking. The strips were then rinsed in freshly made equilibration buffer-2 (50 mM Tris-HCl, pH 8.8, $6 \mathrm{M}$ urea, 30\% glycerol, 2\% SDS, a trace amount of bromophenol blue and $45 \mathrm{mg} / \mathrm{ml} \mathrm{DTT)} \mathrm{for} 10$ minutes with gentle shaking. Next, the IPG strips were rinsed in SDS gel running 


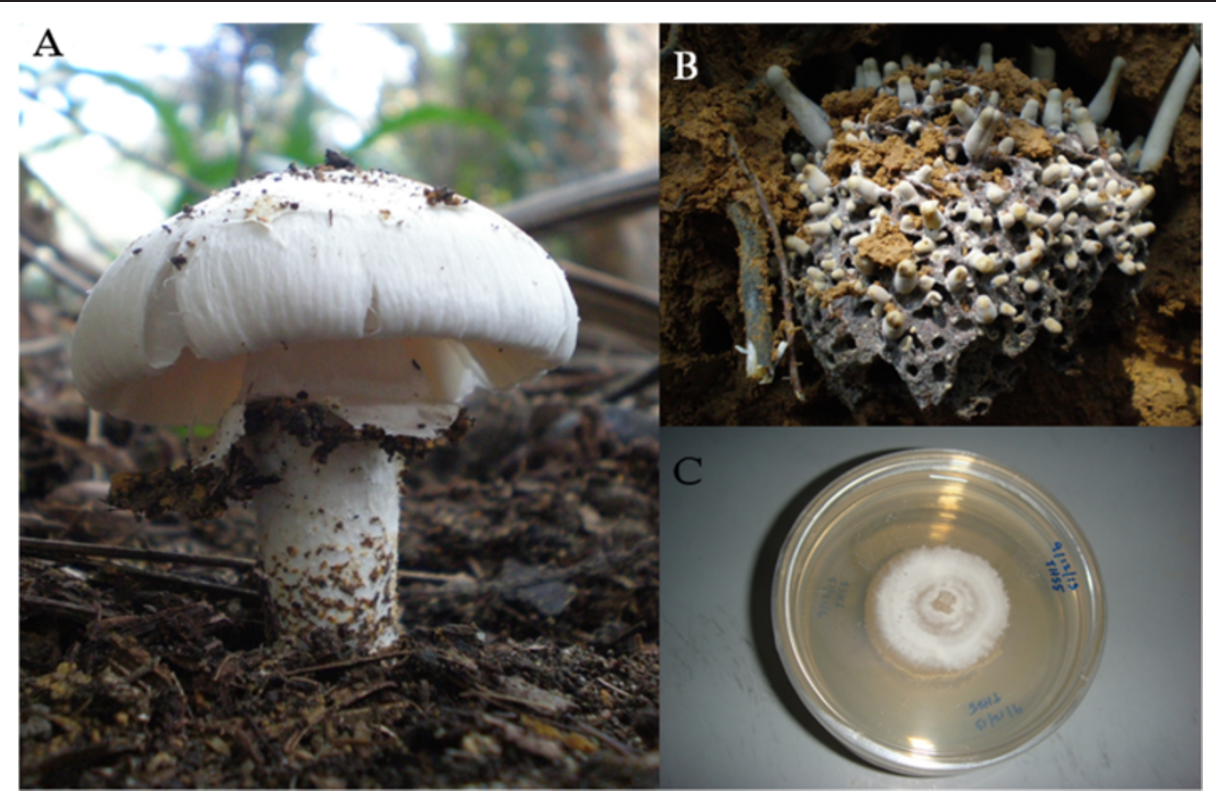

Figure 4 Termite mushroom during different developmental stages. (A) Basidiomata of Termitomyces heimii. (B) Primordia growing on termite nest. (C) Termitomyces heimii mycelium.

buffer and placed on the top of the SDS gels (12\% gels). The SDS gels were run at $15^{\circ} \mathrm{C}$ until the dye front ran out of the gels.

\section{Image scan and data analysis}

Gel images were immediately scanned following SDSPAGE using Typhoon TRIO (GE Healthcare). The scanned images were analysed with PDQuest 2-D analysis software (Bio-Rad), and multiplex gel images were generated by cross-gel analysis using DeCyder software (version 6.5, GE Healthcare). Quantitative and statistical analyses of changes in the spots were performed with DeCyder software (GE Healthcare).

\section{Protein identification by mass spectrometry Spot picking and trypsin digestion}

Spots of interest were picked up using the Ettan Spot Picker (Amersham BioSciences) based on the in-gel analysis and spot picking design by DeCyder software. The gel spots were washed several times and digested in-gel with modified porcine trypsin protease (Trypsin Gold, Promega). The digested tryptic peptides were desalted by Zip-tip C18 (Millipore). Peptides were eluted from the Zip-tip with $0.5 \mu \mathrm{l}$ matrix solution ( $\alpha$-cyano-4-hydroxycinnamic acid, $5 \mathrm{mg} / \mathrm{ml}$ in $50 \%$ acetonitrile, $0.1 \%$ trifluoroacetic acid, $25 \mathrm{mM}$ ammonium bicarbonate) and spotted on the AB SCIEX MALDI plate (Opti-TOF ${ }^{\mathrm{sx}} 384$ well insert).

\section{Mass spectrometry}

MALDI-TOF MS and TOF/TOF tandem MS/MS were performed on an AB SCIEX TOF/TOF 5800 System (AB
SCIEX, Framingham, MA). MALDI-TOF mass spectra were acquired in reflectron positive ion mode, averaging 4000 laser shots per spectrum. TOF/TOF tandem MS fragmentation spectra were acquired for each sample, averaging 4000 laser shots per fragmentation spectrum on each of the 7-10 most abundant ions present in each sample (excluding trypsin autolytic peptides and other known background ions).

\section{Database search}

Both the resulting peptide mass spectra and associated fragmentation spectra were submitted to a GPS Explorer workstation equipped with the MASCOT search engine (Matrix science) to search the non-redundant database of the National Center for Biotechnology Information (NCBInr). Searches were performed without constraining protein molecular weight or isoelectric point, with variable carbamidomethylation of cysteine and oxidation of methionine residues and with one allowed missed cleavage site. Candidates with either a protein score C.I.\% or ion C.I.\% more than 95 were considered significant.

\section{Abbreviations}

2D-DIGE: 2 Dimensional difference gel electrophoresis; CHAPS: 3-[(3-Cholamidopropyl) dimethylammonio]-1-propanesulfonate;

TCA: Trichloroacetic acid; MS: Mass spectrometry; MALDI TOF/TOF: Matrix-assisted laser desorption/ionization/ time-of-flight; KEGG: Kyoto encyclopedia of genes and genomes; DTT: Dithiothreitol; IEF: Isoelectrical focusing; IPG: Immobilized pH gradient; STRING: Search Tool for the retrieval of interacting genes.

\section{Competing interests}

The authors declare that they have no competing interests. 


\section{Authors' contributions}

NR, JRA, NMR and NMS designed the experiment, MHY, NMJ and NSS were involved in sample collection and culture propagation, NR and NMR performed the experiment, JRA, NR, NMR and NBZ analyse the data, JRA and NR wrote the manuscript. All authors read and approved the final manuscript.

\section{Acknowledgements}

This project was funded by the grant from Ministry of Science Technology and Innovation MOSTI (Grant No.08-05-ABI PB030); the authors would like to thank Dr. Mohd Nazir Basiran (ABI Executive Director) for his kind assistant and help to facilitate this work.

Received: 18 March 2014 Accepted: 25 June 2014

Published: 3 July 2014

\section{References}

1. Natarajan K: South Indian Agaricales V: Termitomyces heimii. Mycologia 1979, 71(4):853-855.

2. Taprab Y, Johjima T, Maeda Y, Moriya S, Trakulnaleamsai S, Noparatnaraporn N, Ohkuma M, Kudo T: Symbiotic fungi produce laccases potentially involved in phenol degradation in fungus combs of fungus-growing termites in Thailand. Appl Environ Microbiol 2005, 71(12):7696-7704.

3. Wood TG, Thomas RJ: The mutualistic association between Macrotermitinae and Termitomyces. In Insect-Fungus Interactions. Edited by Wilding N, Collins NM, Hammond PM, Webber JF. London: Academic Press: 1998:69-92.

4. Rouland-Lefèvre C: Termites as Pests of Agriculture. In Biology of Termites: a Modern Synthesis. Edited by Bignell DE, Roisin Y, Lo N. Netherlands: Springer; 2011:499-517.

5. Abd Malek SN, Kanagasabapathy G, Sabaratnam V, Abdullah N, Yaacob H: Lipid Components of a Malaysian Edible Mushroom, Termitomyces heimii Natarajan. Int J Food Prop 2011, 15(4):809-814

6. Tsai SY, Wu TP, Huang SJ, Mau JL: Nonvolatile taste components of Agaricus bisporus harvested at different stages of maturity. Food Chem 2007, 103:1457-1464.

7. Shimizu M, Yuda N, Nakamura T, Tanaka H, Wariishi H: Metabolic regulation at the tricarboxylic acid and glyoxylate Cycles of the lignin-degrading basidiomycetes Phanerochaete chrysosporium against exogenous addition of vanillin. Proteomics 2005, 5:3919-3931.

8. Matsuzaki F, Shimizu M, Wariishi H: Proteomic and metabolomic analyses of the white-rot fungus Phanerochaete chrysosporium exposed to exogenous benzoic acid. J Proteome Res 2008, 7:2342-2350.

9. Horie K, Rakwal R, Hirano M, Shibato J, Nam HW, Kim YS, Kouzuma Y, Agrawal GK, Masuo Y, Yonekura M: Proteomics of two cultivated mushrooms sparassis crispa and hericium erinaceum provides insight into their numerous functional protein components and diversity. J Proteome Res 2008, 7(5):1819-1835.

10. Cheng CK, Au CH, Wilke S, Stajich J, Zolan M, Pukkila P, Kwan HS: 5'-Serial Analysis of Gene Expression studies reveal a transcriptomic switch during fruiting body development in Coprinopsis cinerea. BMC Genomics 2013, 14(1):195.

11. Lau CC, Abdullah N, Shuib AS, Aminudin N: Proteomic analysis of antihypertensive proteins in edible mushrooms. J Agric Food Chem 2012 60(50):12341-12348.

12. Baars JJ, Op den Camp HJ, van der Drift C, Joordens JJ, Wijmenga SS, Van Griensven LJ, Vogels GD: 15 N-NMR study of ammonium assimilation in Agaricus bisporus. Biochim Biophys Acta 1996, 1310(1):74-80.

13. Noor S, Punekar NS: Allosteric NADP-glutamate dehydrogenase from aspergilli: purification, characterization and implications for metabolic regulation at the carbon-nitrogen interface. Microbiology 2005 151(Pt 5):1409-1419.

14. Sakamoto Y, Nakade K, Sato T: Characterization of the post-harvest changes in gene transcription in the gill of the Lentinula edodes fruiting body. Curr Genet 2009, 55(4):409-423.

15. Spanikova S, Biely P: Glucuronoyl esterase-novel carbohydrate esterase produced by Schizophyllum commune. FEBS Lett 2006, 580(19):4597-4601.

16. van den Brink J, De Vries RP: Fungal enzyme sets for plant polysaccharide degradation. Appl Microbiol Biotechnol 2011, 91(6):1477-1492.

17. Yang $F, X u B, L i J$, Huang Z: Transcriptome analysis of Termitomyces albuminosus reveals the biodegradation of lignocellulose. Wei Sheng Wu Xue Bao 2012, 52(4):466-477.
18. Ohkuma M, Shimizu H, Thongaram T, Kosono S, Moriya K, Trakulnaleamsai $\mathrm{S}$, Noparatnaraporn N, Kudo T: An alkaliphilic and xylanolytic Paenibacillus species isolated from the gut of a soil-feeding termite. Microbes Environ 2003, 18(3):145-151.

19. Parker J: Elongation Factors; Translation. In Encyclopedia of Genetics. Edited by Brenner S, Miller JH. New York: Academic Press; 2001:610-611.

20. Chen L, Zhang B-B, Cheung PCK: Comparative proteomic analysis of mushroom cell wall proteins among the different developmental stages of pleurotus tuber-regium. J Agric Food Chem 2012, 60(24):6173-6182.

21. Belozerskaia TA, Gessler NN: [Reactive oxygen species and the strategy of the antioxidant defense in fungi: a review]. Prikl Biokhim Mikrobiol 2007, 43(5):565-575.

22. Wood ZA, Schroder E, Robin Harris J, Poole LB: Structure, mechanism and regulation of peroxiredoxins. Trends Biochem Sci 2003, 28(1):32-40.

23. Cobos R, Barreiro C, Mateos RM, Coque JJ: Cytoplasmic- and extracellular-proteome analysis of Diplodia seriata: a phytopathogenic fungus involved in grapevine decline. Proc Natl Acad Sci U S A 2010, 8:46.

24. Patyshakuliyeva A, Jurak E, Kohler A, Baker A, Battaglia E, De Bruijn W, Burton KS, Challen MP, Coutinho PM, Eastwood DC, Gruben BS, Mäkelä MR, Martin F, Nadal M, van den Brink J, Wiebenga A, Zhou M, Henrissat B, Kabel M, Gruppen H, de Vries RP: Carbohydrate utilization and metabolism is highly differentiated in Agaricus bisporus. BMC Genomics 2013, 14:663.

25. Cordente AG, Heinrich A, Pretorius IS, Swiegers JH: Isolation of sulfite reductase variants of a commercial wine yeast with significantly reduced hydrogen sulfide production. FEMS Yeast Res 2009, 9(3):446-459.

26. El-Baky HA, Linke D, Nimtz M, Berger RG: PsoP1, a milk-clotting aspartic peptidase from the basidiomycete fungus Piptoporus soloniensis. J Agric Food Chem 2011, 59(18):10311-10316.

27. Anderson E, Burns C, Zolan ME: Global gene expression in Coprinopsis cinerea meiotic mutants reflects checkpoint arrest. G3 (Bethesda) 2012, 2(10):1213-1221.

28. Srivatsan A, Wang JD: Control of bacterial transcription, translation and replication by (p)ppGpp. Curr Opin Microbiol 2008, 11(2):100-105.

29. Szklarczyk D, Franceschini A, Kuhn M, Simonovic M, Roth A, Minguez $P$, Doerks T, Stark M, Muller J, Bork P, Jensen LJ, Von Mering C: The STRING database in 2011: functional interaction networks of proteins, globally integrated and scored. Nucleic Acids Res 2011, 39:D561-D568.

30. Lakshman DK, Natarajah SS, Garett WM, Dhar AK: Optimized protein extraction methods for proteomic analysis of Rhizoctimia solani. Mycologia 2008, 100(6):867-875.

\section{doi:10.1186/0717-6287-47-30}

Cite this article as: Rahmad et al: Comparative proteomic analysis of different developmental stages of the edible mushroom Termitomyces heimii. Biological Research 2014 47:30.

\section{Submit your next manuscript to BioMed Central and take full advantage of:}

- Convenient online submission

- Thorough peer review

- No space constraints or color figure charges

- Immediate publication on acceptance

- Inclusion in PubMed, CAS, Scopus and Google Scholar

- Research which is freely available for redistribution 